\title{
Um Novo Marco Legal para a Ciência, Tecnologia e Inovação (CTI)
}

Está circulando e sendo discutido no Brasil uma minuta do Projeto de Lei 2177/11, que trata da criação de um novo Código Nacional de Ciência, Tecnologia e Inovação. Este documento foi elaborado por um grupo de trabalho vinculado ao CONSECTI-CONVAP, o Conselho Nacional de Secretários Estaduais para Assuntos de CTI e o Conselho Nacional das Fundações de Amparo à Pesquisa.

É preciso, em primeiro lugar, elogiar e valorizar a iniciativa destas instituições e deste grupo de trabalho em trazer este tema ao debate e no árduo trabalho de elaborar e produzir uma nova legislação que facilite as atividades de CTI no Brasil.

É fato que a área de CTI no Brasil não vem alcançando os resultados necessários para cumprir seu relevante papel no desenvolvimento econômico e social do País. Tampouco tem conseguido exercer com plenitude seu potencial, considerando a qualidade de nossas Universidades, a capacidade inovadora das empresas, as politicas públicas de fomento, indução e incentivo. A burocracia nos impede.

O Brasil já se encontra defasado na legislação de CTI mesmo quando comparado a paises em desenvolvimento, como a Índia e a China, sendo imperioso que se reverta o cenário brasileiro atual.

Escutei recentemente um "causo" que é "figurativo", mas ilustra o entrave burocrático por que passa a legislação de CTI do Brasil: Um pesquisador solicitou permissão a órgão do governo brasileiro para realizar sua pesquisa. Enquanto isso, terminou sua pesquisa em um laboratório europeu, patenteou nos EUA, está produzindo na Índia e o produto já está sendo consumido no Brasil. Ainda aguarda a autorização para conduzir a pesquisa no Brasil.

O Projeto de Lei tenta concentrar em um único documento, toda a regulamentação que se encontrava espalhada em outras inúmeras leis, algumas já muito antigas. Cito a seguir alguns aspectos relevantes contemplados por este projeto de lei: a) Propõe um sistema simplificado para aquisições e contratações desvinculado da tão famosa Lei 8666, cuja morosidade de procedimentos vem inviabilizando projetos cientificos e de inovação; b) facilita os processos de importação, evitando que os equipamentos fiquem parados nos portos pagando estadia, pois os fiscais não estão acostumados a este tipo de procedimento; c) reinterpreta o regime de "dedicação exclusiva" imposto aos pesquisadores brasileiros, propiciando que estes participem efetivamente do processo de inovação nas empresas e possam receber por isso; d) os instrumentos jurídicos decorrentes da atividade de CTI terão seus prazos vinculados à duração do projeto, sem limitação de aditivos, desde que justificados, podendo ser acrescido recursos suficientes para fazer frente às despesas; e) define que todo aporte de capital em ações de CTI são considerados como investimento, podendo ser abatido do imposto de renda pelas empresas; f) as prestações de contas tornam-se mais flexíveis; g) os remanejamentos podem ser feitos com justificativa posterior, mantendo-se foco na análise do resultado do projeto e não na contabilidade; h) as FAP's e CNPq podem incluir taxa administrativa para que a prestação de contas seja feita por Fundação pré-credenciada, e não mais pelo pesquisador.

Como visto, são muitos os avanços. As discussões sobre o conteúdo deste projeto de lei ainda trazem questionamentos. Como exemplos, argumenta-se que poderia ter avançado mais no sistema de aquisições e licitações proposto; as instituições privadas de CTI, mesmo as sem fins lucrativos, não estariam devidamente contempladas no atual documento. E há dúvidas quanto à operacionalização de uma única lei contendo tantos assuntos.

O mais importante, sem dúvida, é ter trazido o tema para discussão e o fato que hoje temos uma proposta para avaliar. Há que se discutir, que se alterar e de se melhorar, que é o estágio atual deste documento. A seguir, ainda restarão dois grandes e enormes desafios: primeiro, sua aprovação pelo Congresso e, a seguir, o convencimento dos órgãos de controle de que esse é o código a ser usado para fiscalizar as atividades de ciência, tecnologia e inovação.

Ainda não dá para comemorar, mas esta noticia é muito bem vinda.

Ronaldo Paranhos

Diretor de Projetos e Inovação da UENF

Prof. Associado do LAMAV-CCT-UENF. 